\title{
Trade Politics is Local Politics: Subnational Interests and Commercial Policy in Argentina*
}

\author{
Política comercial es política local: intereses subnacionales \\ y politica comercial en Argentina
}

\author{
ANTHONY A. PEZZOLA \\ College of Integrative Sciences and Arts, Arizona State University
}

\begin{abstract}
Although it is generally thought that larger industries have greater political influence, by directly measuring the subnational importance of industries, this article suggests that it is the importance of industries within political jurisdictions, not their absolute size, that determines their domestic political leverage. Through the evaluation of Argentina's deviations from Mercosur's common external tariff and from intra-regional free trade, this study evidences that subnational economic interests directly influence Argentina's trade policies. For both large and small industries, their relative importance within the provinces that they inhabit provides the political clout necessary to gain preferential trade policy outcomes.
\end{abstract}

Key words: Argentina, Mercosur, trade protection, subnational politics, federalism

\section{RESUMEN}

Comúnmente se cree que las industrias más grandes tienen mayor influencia política. Este artículo cuestiona esa creencia. Mediante una evaluación de la importancia de las industrias a nivel subnacional en Argentina, este estudio muestra que la influencia política de los industriales no está determinada por el tamaño absoluto de las industrias. En cambio, su influencia política depende del nivel de importancia de las mismas dentro de las jurisdicciones políticas a las que éstas pertenecen. A través de la evaluación de las desviaciones en Argentina del arancel externo común del Mercosur y del libre comercio intrarregional, este trabajo muestra que los intereses económicos subnacionales influencian directamente las políticas de comercio de Argentina. La importancia relativa que tanto pequeñas y grandes industrias tienen dentro de las provincias explica los niveles de influencia política necesaria a la hora de obtener políticas comerciales preferenciales.

Key words: Argentina, Mercosur, protección comercial, politica subnacional, federalismo

\footnotetext{
AcKNOwLEDGEMENTs: This work was supported by Millennium Science Initiative, Ministry of Economy, Development and Tourism of Chile under Grant R13002. I would like to thank the editors and two anonymous reviewers for their helpful comments and insights.
} 


\section{INTRODUCTION}

Understanding the successful implementation and maintenance of trade policy depends on understanding the polity's structure. Tariffs and tariff concessions are not granted arbitrarily; they reflect political constraints placed on policymakers. This is especially true within preferential trade agreements (PTAs) that must be ratified by legislators. In the early 1990s, the Southern Common Market (Mercosur) between Argentina, Brazil, Paraguay, and Uruguay faced its first crisis as domestic pressure threatened its implementation. As it became clear that leaders intended to implement regional free trade, opposition dramatically increased. At the same time, disagreements over the level of protection granted by the common external tariff (CET) emerged.

Faced with a political climate that threatened to unravel the common market, leaders signed the Protocol of Ouro Preto in 1994. This agreement mitigated domestic opposition by allowing all of the countries to deviate from intraregional free trade and from the CET on numerous products. As a result, Argentina exempted 221 tariff lines from intra-regional free trade and deviated from Mercosur's CET on 1,876 tariff lines (948 above and 931 below). ${ }^{1}$ These deviations provided policymakers with a means of ameliorating political opposition; however, the specific characteristics of industries that caused policymakers to grant them preferential treatment remains unclear. In other word, we do not know what gave specific industries sufficient political clout to threaten the implementation of Mercosur and, therefore, warrant preferential treatment.

Within the federal systems of Latin America, subnational interests sway policy outcomes. Despite this, little attention has been given to how subnational interests influence trade policy within the region. ${ }^{2}$ There is a growing consensus that subnational interests significantly influence Argentine legislators. Scholars see the provincial level as the foundation of Argentine partisan politics (Leiras 2007; Lodola 2011; Suárez Cao 2011; Micozzi 2014). Even the president's ability to influence legislators within her own party depends on the subnational interests at stake and the support of provincial party bosses (Saiegh 2004). Argentine legislators are really provincial party loyalists, responding directly to the goals of provincial parties (Jones 2008). Provinces represent a key electoral reference, this requires legislators to orient their actions towards local voters (Micozzi 2013, 2014) and provincial party delegations represent the main determinant of policy design (Calvo and Leiras 2012). It would, therefore, make sense that subnational economic interests also influence trade policy.

1 In total, including deviations established by other regimes within Mercosur, Argentina exempted 463 HS-8 digit tariff lines from free trade. Within the Protocolo de Ouro Preto Brazil had 28 deviations, Paraguay 427 deviations, and Uruguay 1,018 deviations. Brazil deviated from the CET on 1,259 tariff lines. Deviations from free trade for "sensitive" products is a common occurrence within PTAs as they provide an important mechanisms for cultivating political support and saving otherwise politically unfeasible agreements.

Notable exceptions are Drope (2006), Pezzola (2013), and Murillo and Pinto (2014). 
This research builds on a subset of trade policy literature that identifies the importance of subnational trade sensitivity to explain how legislators vote on trade policy (Baldwin and Magee 2000; Fordham and McKeown 2003; Arce et al. 2008). To investigate the endogenous determinants of Argentina's trade policy within Mercosur, subnational economic interests are directly incorporated into an extended version of the Grossman-Helpman (1994) "protection for sale" model. Through the analysis of Argentina's exceptions to free trade as well as to Mercosur's CET, this research demonstrates that subnational economic interests strongly influence which industries Argentine policymakers favored. In the same way that Pezzola (2013) demonstrates that parochial interests influence Mexican trade politics, the evidence presented here indicates that the political clout of Argentine industries stems from their relative importance within the subnational economies where they are located. As such, this research adds to the literature on the endogenous formation of trade policy by suggesting that, in countries where political survival depends on the interests of geographically specific sets of voters, looking at the distribution of subnational economic interests and not an industry's absolute size provides a better understanding of which groups politicians favor. This article also provides evidence that the influence of subnational interests in Argentine politics extends beyond the scope of fiscal federalism, providing an important insight into how constituent (regional) interests interact with the political system to influence distributive outcomes. While "provincial party loyalists" may support the policy agenda of the Argentine President in exchange for fiscal transfers to their provincial governments (Siavelis and Morgenstern 2012), this research suggest that Argentine legislators may also be loyal to subnational economic interests.

\section{LITERATURE AND THEORETICAL PREDICTIONS}

Even though the formation of trade policy in Argentina is mainly conducted by the executive branch, this does not mean that legislators do not influence policy outcomes. The ratification process of PTAs provides both deputies and senators with an opportunity to influence the structure of Argentina's agreements. As Putnam (1988) and others point out, the need to ratify any agreement allows domestic actors to influence the content of the agreement during negotiations and, therefore, the shape of the final "win-set". Milner and Rosendorff (1996) demonstrate that legislative ratification, even when the legislature is incompletely informed, forces the Executive to negotiate an agreement that resembles the ideal policy of the legislature. When the division between the legislature and the executive increases, negotiated outcomes tend to favor the interests of the legislature. Even when the legislature does not formally ratify policies, it can still influence outcomes and shape negotiated outcomes (Martin 2000). Hence, even if the Argentine legislature did not formally participate in the Ouro Preto negotiations, there is strong reason to believe that its interests were taken into account. 
Political institutions clearly influence which groups policymakers choose to privilege through trade policy. Weak party systems, electoral systems, the number of veto-points, and presidentialism influence the propensity of policymakers to provide trade patronage (Milner and Rosendorff 1997; McGillivray 2004; Henisz and Mansfield 2006). Comparative large-n studies take into account political systems like Argentina's, where national parties are weak despite a PR electoral system with large jurisdictions, but they only look at general tendencies towards trade protection (Rogowski and Kayser 2002; Evans 2009; Rickard 2012). These studies cannot explain why specific industries receive protection and others do not, or whether policies distribute benefits to subnational interests.

There is ample reason to believe that the magnitude of a country's political jurisdictions directly influences the susceptibility of legislators to the interests of their constituents. Rogowski (1987) argues that large electoral districts and the PR system insulate policymakers from private interests. Mansfield and Busch (1995) and Rogowski and Kayser (2002), however, find that electoral institutions matter in exactly the opposite direction. One of the problems with the argument that a jurisdiction's magnitude makes politicians more or less resistant to lobbying by private interests is that it over specifies the influence of this characteristic of electoral systems.

Electoral systems by themselves do not insulate legislators from parochial interests; rather, it is a country's electoral and party institutions together that determine how responsive representatives are to national partisan interests. While legislators in some PR systems may be insulated from parochial interests, weak party systems tend to drive legislators towards developing strong ties with local interests (Crisp et al. 2004). Although we may "all concede [that strong parties] are furthered by list-system PR" (Rogowski 1987: 208), PR systems do not necessarily provide legislative autonomy from private interests.

Other institutions also influence the responsiveness of representatives to private interests within their jurisdictions. National party leaders with the ability to sanction members are more able to advance policy reforms that favor national officials' policy goals (Cox and McCubbins 2001). On the other hand, local control of candidate access to the ballot, as often happens in Argentina, amplifies the power of subnational interest over legislators. The open primary system often used in Argentina decreases party unity (Carey 2000) and has a centrifugal effect on policymaking, distributing power to local leaders (Rohde 1991). Federalism encourages the organization of parties at subnational level, which increases the political salience of regional interests (Weyland 1996; Mainwaring 1999).

The rules that govern the operation of political parties may also have a centrifugal effect on political power and increase the influence of subnational interests. Party systems like Argentina's that give provincial or municipal political leaders the ability to deliver blocs of votes to candidates, increases the influence 
of subnational interests over national legislators (Ames 1994). Furthermore, the influence of Argentine governors and provincial party bosses over the political careers of legislators increases the authority of subnational interests over national policymaking (Jones et al. 2001; Siavelis and Morgenstern 2012).

We know that politicians react to interests within specific political jurisdictions. Once we begin to examine the types of policies that policymakers propose and support it becomes clear that constituent interests influence policy outcomes (Finger and Harrison 1994; Baldwin and Crowley 2001). ${ }^{3}$ There is also clear evidence that trade sensitivity at the subnational level influences how legislators vote on trade policy (Baldwin and Magee 2000; Arce et al. 2008). Grossman and Helpman (2005) find that when legislators are tied to particular geographic jurisdictions, differences in the distribution of industries across jurisdictions induce protection. Even if individual voters have no clear preferences on trade policy, electoral competition requires local parties and the representatives of geographically specific jurisdictions to deliver economic benefits to their region. To the degree that an industry plays an important role within a subnational economy, both voters and politicians have a special interest in protecting that industry (Cassing et al. 1986).

The most common mechanism linking economic interests with trade policy is political contributions (e.g. lobbying). However, the specific economic characteristics of a jurisdiction can also have selection and influence effects over elected officials at all levels. Fordham and McKeown (2003) show that local economic interests have a direct influence over candidate recruitment, increasing their sensitivity to said interests. This makes it easier for local business and labor interests to gain access to legislators, because they are already predisposed to the interests of labor and industry within their jurisdiction. The perceived quality of information provided by locally important industries should also grant greater political leverage to subnationally important industries (Bennedsen and Feldmann 2002).

Even if individual legislators are unconcerned with servicing constituent interests, as provincial party loyalists, they should respond to the interests of their provincial party bosses, who have a clear interest in protecting important industries within their jurisdiction. This is because the standing of parties, at all levels of government, depends on the relationship between the party and specific geographic constituencies. Supporting policies detrimental to the economic health of their province or to the well-being of important economic actors within it is surely a recipe for electoral failure.

Given that subnational economic interests should have strong influence over policymakers in Argentina, we can expect that policies will tend to privilege 
these interests. This suggests that Argentine trade policy should give preferential treatment to important industries at the subnational level:

Hypothesis 1: Industries of greater relative subnational importance are more (less) likely to benefit from greater protection (liberalization) within Argentina's exceptions to intra-regional free trade and to Mercosur's CET.

Before protecting an industry, politicians evaluate the aggregate welfare effects of protectionism against the political support that it generates. Grossman and Helpman (1994) argue that the elasticity of demand for an industry's products directly influences its likelihood of receiving protection. Protecting sectors with high import elasticity generates negative terms-of-trade effects and, therefore, a deadweight loss to society. All else being equal, politicians prefer to protect industries where the deadweight loss is lower.

Hypothesis 2a: The import elasticity of an industry has a negative (positive) association with greater protection (liberalization).

However, this suggests that national welfare, not the interests of specific constituencies, plays a fundamental role in determining which industries benefit from deviations. If the preferences of policymakers depend on the interests of specific geographic constituencies, they should be indifferent to aggregate welfare losses.

Hypothesis $2 b$ : The import elasticity of an industry has an insignificant influence on the likelihood of Argentine industries receiving preferential treatment within Mercosur's trade regime.

Whether an industry seeks protection plays an important role in trade policy formation. Just as politicians face costs for protecting an industry, seeking protection imposes costs on interested parties. Faced with finite resources to influence policymakers, industries, labor organizations, and voters will use their resources where they have the greatest impact, which may include seeking other types of policy outcomes. Hence, it is necessary to account for the utility of lobbying for trade protection.

The industries characterized by high levels of intra-industry trade (IIT) are often thought to be less likely to lobby for protection (Goodhart 2015). This is because IIT represents an evolution towards a high degree of specialization and, therefore, comparative advantage. This reduces the number of potential losers from liberalization and makes it more difficult for import competing sectors to successfully lobby for protection. Fear of retaliation from foreign producers of substitute goods may also limit the likelihood of producers to seek protection (Marvel and Ray 1987); and, export oriented firms may use norms of reciprocity to limit domestic protection and ensure tariff reductions in the partner country. Chase (2005) argues that firms engaged in ITT can benefit from the expanded markets of free trade agreements and should support their formation. Unfortunately, limited empirical evidence exists to support these arguments. 
Even if IIT were non-competitive, IIT may generate increased protection. Gilligan (1997) argues that the monopolistic nature of IIT causes lobbying to essentially becomes a private good, which increases the likelihood of lobbying by eliminating free-riders. Where electoral institutions encourage politicians to cater to specific geographic constituencies, the returns to lobbying are higher and IIT should have a stronger impact on policy outcomes (Kono 2009). Bombardini and Trebbi (2012) argue that firms are more likely to lobby individually when their products are characterized by a high degree of differentiation. This suggests the following hypothesis:

Hypothesis 3: Product groups exhibiting higher degrees of intra-industry trade are more likely to receive preferential treatment within Argentina's deviation from intra-regional free trade and the CET.

\section{Control Variables}

Studies of the endogenous determinants of trade policy often incorporate an industry's average wage to capture aspects of the industry's political clout, propensity to lobby for protection, and the capacity of workers to organize. However, the relationship between wages and protection is unclear. Especially in developing countries, high paying manufacturing jobs are relatively scarce and highly desirable; hence, we would expect politicians to protect industries that provide these jobs (Milner and Mukherjee 2009). On the other hand, wages are also seen as a proxy for a sector's competitiveness, which would reduce the likelihood of a high wage industry seeking protection (Lee and Swagel 1997). Industries characterized by higher wages may also be less likely to lobby for protection, since higher wages decrease the role of capital in the value of production and decrease the potential losses from foreign competition for owners of industry specific capital (Finger and Harrison 1994).

The level of import penetration faced by an industry has become a standard component of models of endogenous trade policy formation (Goodhart 2015). There is growing consensus that for organized industries a lower degree of import penetration increases demands for protection (Maggi and RodríguezClare 2000). If domestic output plays a greater role in the market, producers have more to gain from an increase in domestic prices. This indicates that lower import penetration increases (decreases) the likelihood of an industry receiving protection (liberalization). On the other hand, we may expect greater (less) support for protection (liberalization) if greater import penetration indicates that domestic producers are in decline (Baldwin and Robert-Nicoud 2007). 


\section{Alternative Explanations}

To test whether subnational economic interests influence the structure of Argentine exceptions with Mercosur, the importance of an industry within the national economy must be considered. Scholars have long argued that larger industries are more likely to receive preferential treatment. Size provides an inherent advantage that allows industries to penetrate government institutions and politicians' offices (Magee et al. 1989). Larger industries are assumed to have more resources to lobby politicians and support the electoral campaigns of "friendly" officials (Grossman and Helpman 1994). This suggests that larger industries are more likely to receive trade protection.

Since receiving preferential treatment depends on an industry's ability to attract the attention of policymakers, many studies have employed the political concentration of an industry and its interaction with its absolute size to measure the industry's political clout. Although they do not directly measure the relative subnational importance of an industry, these indicators have been employed as proxies for subnational importance. For many, greater concentration increases the potential for protection (McGillivray 2004); while for others, disperse industries have more success gaining political support because they are present in multiple jurisdictions (Pincus 1975).

\section{MEASURING SUBNATIONAL ECONOMIC INTEREST}

To understand why politicians cater to some interests and not others, it is not enough to understand how political institutions cause politicians to respond to narrow interests. Although political institutions determine the extent to which geographically specific interests influence policy outcomes, they cannot tell us anything about what those interests are. It is the specific distribution of economic activity across political jurisdictions that determines the interests of the constituents who elect politicians and, therefore, policy preferences.

Unfortunately, most measures of the importance of industries within and across jurisdictions misspecify the factors behind their importance. Scholarship on trade policy formation has long accepted the argument that an industry's political concentration effects its importance to subnational representatives and, therefore, its ability to influence policy (Pincus 1975; Caves 1976; Cassing et al. 1986; Rogowski 2002; McGillivray 2004), ${ }^{4}$ but most of this literature neglects Cave's (1976) insight that it is the relative role that industries play within a country's jurisdictions that grants them influence. Measures of political concentration only account for the presence of an industry across jurisdictions independent of other economic activity taking place within the jurisdictions

This is what Busch and Reinhardt (1999) call political concentration, and they make a clear distinction between it and geographic concentration. Due to data limitations, this paper does not attempt to assess the influence of geographic concentration. 
where it is located. The resulting measure, therefore, ignores the relative importance of an industry to voters and politicians within and across specific political jurisdictions.

Although McGillivray (2004) echoes Cave's point by explaining that industries that "receive the assistance they desire are large enough that their impact in each district in which they are located is significant" $(2004,58)$, she and other scholars (e.g. Milner and Rosendorff 1997; Rogowski et al. 1999; Bombardini and Trebbi 2012) use an industry's political concentration independent of the location of other industries to measure its significance within jurisdictions. Setting aside the influence that geographic or political concentration may have on collective action costs, the underlying logic of the political concentration argument states that for any given industry, regardless of it size, the industry will be more successful in attracting the attention of policymakers to the extent that it is politically concentrated. ${ }^{5}$ This is because it becomes sufficiently large to attract the attention of its representatives. Unfortunately, this logic ignores the economic characteristics of the jurisdictions in which the industry is thought to have influence in. Since competition across different groups decreases the amount of private goods (e.g. protection) that politicians must provide, representatives of economically heterogeneous jurisdictions will be less motivated, certeris paribus, to provide protection to local industries. Moreover, if we assume that politicians only devote attention to a group's interests in proportion to their likely influence over their political career (Salamon and Siegfried 1977), the importance of any industry within a jurisdiction depends upon its importance relative to all other economic activity in the same jurisdiction.

The political concentration and absolute size of an industry by themselves tell us nothing about the relative subnational importance of an industry, unless all industries have identical spatial distributions. Depending on the political location of other industries, a large and political dispersed industry may be relatively important in one or many jurisdictions, but not in all jurisdictions. At the same time, depending on the distribution of other industries a small concentrated industry may be relatively dominant in one or more jurisdictions giving it greater political influence than its size in the national economy would suggest. This is an especially important point when malapportionment over represents some jurisdictions. Therefore, in order to understand the political influence of an industry over policymakers, the economic geography of each political jurisdiction must be taken into account.

Dispensing with the assumption of homogenous spatial distribution of industrial activity, we can clearly see that it is not just the political concentration of an industry or its absolute size that affects its political influence. Assume that a country has three industries (A, B, C) which respectively make up 50\%, 40\%, and

Pincus (1975), Trefler (1993), Rogowski (2002) and others argue that political concentration limits the influence of industries as they are associated with fewer electoral districts. 
$10 \%$ of the country's economy and five equal sized political jurisdictions $(v, w, x$, $y, z)$, all with equally sized economies. If each industry's activity is distributed evenly across all the jurisdictions, then each industry's relative weight at the subnational level will be equal to its relative weight in the national economy. However, as can be seen in Table 1a, if we maintain the assumption that the jurisdictions' economies are of equal size, a high level of political concentration in a single industry (industry C) significantly alters the spatial concentration and distribution of the other industries, increasing the relative subnational importance of the highly concentrated industry $(\mathrm{C})$ in at least one jurisdiction $(z)$. The concentration of industry $C$ in jurisdiction $z$, gives this relatively tiny industry ( $10 \%$ of the national economy) a dominate role in $z^{\prime}$ s economy ( $40 \%$ of the local economy) and, therefore, a political stronghold. Furthermore, the different geographic distribution of the other industries generates the possibility that industry $\mathrm{C}$ could use its importance within jurisdictions $y$ and $z$ to form a coalition of representatives from $x, y$, and $z$ to support the interests of industries $\mathrm{B}$ and $\mathrm{C}$.

Table 1a. Relative Importance of Industries with Jurisdictions with Equal Sized Subnational Economies

Absolute Value of Production

\begin{tabular}{ccccccc}
\hline Industry & $v$ & $w$ & $x$ & $y$ & $z$ & Total Production \\
\hline A & 14 & 12 & 9 & 9 & 6 & 50 \\
B & 6 & 8 & 11 & 9 & 6 & 40 \\
C & 0 & 0 & 0 & 2 & 8 & 10 \\
Jurisdiction Total & 20 & 20 & 20 & 20 & 20 & 100 \\
\hline Industry & \multicolumn{7}{c}{ Relative Importance within Jurisdictions } \\
A & $v$ & $w$ & $x$ & $y$ & $z$ & \\
B & $70 \%$ & $60 \%$ & $45 \%$ & $45 \%$ & $30 \%$ & \\
C & $30 \%$ & $40 \%$ & $55 \%$ & $45 \%$ & $30 \%$ & \\
\hline
\end{tabular}


Table 1b. Relative Importance of Industries as with Jurisdictions with Different Sized Subnational Economies

\begin{tabular}{ccccccc}
\multicolumn{7}{c}{ Absolute Value of Production } \\
\hline Industry & $v$ & $w$ & $x$ & $y$ & $z$ & Total Production \\
A & 17 & 11 & 8 & 8 & 6 & 50 \\
B & 14 & 8 & 8 & 6 & 4 & 40 \\
C & 8 & 1 & 1 & 0 & 0 & 10 \\
Jurisdiction Total & 39 & 20 & 15 & 14 & 10 & 100 \\
\hline \multicolumn{7}{c}{ Relative Importance within Jurisdictions } \\
\hline Industry & $v$ & $w$ & $x$ & $y$ & $z$ & \\
A & $44 \%$ & $55 \%$ & $47 \%$ & $57 \%$ & $60 \%$ & \\
B & $36 \%$ & $40 \%$ & $47 \%$ & $43 \%$ & $40 \%$ & \\
C & $21 \%$ & $5 \%$ & $6 \%$ & $0 \%$ & $0 \%$ & \\
\hline
\end{tabular}

Table 1c. Country with Concentrated and Highly Concentrated Economic Activity, but Second Largest Industry at the National Level Lacks "Stronghold" Jurisdiction

\begin{tabular}{ccccccc}
\multicolumn{7}{c}{ Absolute Value of Production } \\
\hline Industry & $v$ & $w$ & $x$ & $y$ & $z$ & Total Production \\
A & 23 & 15 & 8 & 3 & 1 & 50 \\
B & 6 & 12 & 10 & 9 & 3 & 40 \\
C & 0 & 0 & 0 & 2 & 8 & 10 \\
\hline Jurisdiction Total & 29 & 27 & 18 & 14 & 12 & \\
\hline Industry & Relative Importance within Jurisdiction & \\
A & $v$ & $w$ & $x$ & $y$ & $z$ & \\
B & $79 \%$ & $56 \%$ & $44 \%$ & $21 \%$ & $8 \%$ & \\
C & $21 \%$ & $44 \%$ & $56 \%$ & $64 \%$ & $25 \%$ & \\
\hline
\end{tabular}

If the size of the jurisdictions' economies varies, it is impossible to estimate the relative importance of an industry across jurisdictions using its political concentration and absolute size. Although a relatively large industry at the national level must play an important role in a least one jurisdiction, we cannot say anything else about its political clout without accounting for the distribution of the other industries. If industries are concentrated in the same jurisdictions, their relative importance at the subnational level will closely reflect their importance at the national level and their political concentration will have little effect on their relative importance (see Table 1b). If different parts of a country have different economic characteristics, which is typically 
the case, the spatial distribution of industries can have a significant impact on their relative political influence within different jurisdictions. Table 1c shows a spatial distribution of activity such that industries are concentrated in different jurisdictions. The resulting distribution generates stronghold jurisdictions for each of the industries (in jurisdictions $v, y$, and $z$ respectively) and gives industry $\mathrm{B}$ the same degree of relative importance in jurisdictions $v$ and $x$ as the larger industry A has in jurisdictions $w$ and $y$. If we include non-industrial activities like services, commerce, and government in our example, which often account for a significant portion of economic activity, it becomes impossible to calculate the relative importance of a specific activity using only its size and political concentration.

\section{THE EMPIRICAL MODELS AND MEASURES}

In 1995, Argentina deviated from either Mercosur's CET or from intra-regional free trade on close to $30 \%$ of the 9,279 tariff lines representing manufactured and semi-manufactured products. To test the hypothesis that Argentina's trade policy exhibits a higher likelihood of concessions to industries of relative importance within its provinces, regardless of the industries' relative importance in the national economy, the economic and political economy variables discussed below have been integrated into several multilevel models that estimate the influence of subnational and national interests on the likelihood of deviations. In the case of deviations from free trade a multilevel logit model is used. For deviations from the CET a multilevel multinomial logit model is used.

\section{Observed Dependent Variable}

This article studies how the economic interests of subnational constituencies influence the likelihood of an industry receiving preferential treatment. Any protectionist deviation from intra-regional free trade has been coded as a 1 and all other tariff lines are coded as 0 . Deviations from the CET have been coded as a multinomial variable; protectionist deviations, regardless of size, are coded as 2 , liberal deviations are coded as 1 , and all other tariff lines are as $0 .^{6}$

\section{Observed Independent Variables}

To measure the importance of an industry within and across different political jurisdictions, an indicator of subnational importance must be employed. If we dispense with the assumption of a homogenous spatial distribution of industrial activity, the political concentration and absolute size of an industry tell us very

Data for protectionist deviations in 1995 were provided by the Secretariat of Political Economy of the Argentine Ministry of Economy and Production. 
little about the relative subnational importance of an industry with specific geographic constituencies. This means that we must measure the importance of each industry relative to all other economic activity within the jurisdictions that it inhabits. For this purpose, the variable Subnational Production is calculated by aggregating the relative importance of each industry within the economy of each of Argentina's provinces and the city of Buenos Aires. ${ }^{7}$ By dividing the value of production of an industry in each jurisdiction by the total size of the jurisdiction's economy, we measure its relative importance to voters and politicians within the jurisdiction. Aggregating these values across jurisdictions provides a measure of the relative subnational importance of the industry to voters across Argentina. ${ }^{8}$

Obtaining an accurate measure of import elasticity for any country is extremely difficult, especially at a high level of product desegregation. Following Olarreaga et al. (1999), Argentina's market share of world imports is used as a proxy for the terms-of trade effects of protection. ${ }^{9}$ Although imperfect, this proxy can be easily calculated at all levels of product desegregation and does not rely on problematic estimates of import elasticity. Therefore, Argentina's Import Share replaces import elasticity. When modelling deviations from intra-regional free trade, imports from Brazil, Paraguay, and Uruguay are used; while imports from the rest of the world are used when modelling deviations from the CET.

The level of IIT is calculated using the Gruber-Lloyd Index. The index of IIT is calculated both at the industry level $\left(I I T_{i}\right)$ and at the product level $\left(I I T_{p}\right)$. While norms of reciprocity may deter protectionism by industries characterized by high levels of $I I T_{i}$, the need of politicians to cater to specific geographic constituencies provide incentives for politicians to protect firms that produce products with high levels of IIT . The level of IIT with regional counterparts is used when modelling deviations from free trade and IIT with the rest of the world for deviations from the CET.

The other variables utilized are calculated as follows. An industry's average wage $\left(\right.$ Wage $\left._{i}\right)$ is equal to the total wages and salaries paid by an industry divided by the total number of employees in the industry. The degree of import penetration of an industry (Import Penetration ${ }_{i}$ ) is equal to the value of imports associated with an industry divided by the industry's total value of production. The overall size of an industry is measured using its total value of production (Production $_{i}$ ). The Political Concentration ${ }_{i}$ of an industry is calculated using a Herfindahl index of employment.

7 In the case of this paper, jurisdictions refer to the Argentine provinces and the independent city of Buenos Aires.

8 A full description of the measure and further discussion of its properties can be found in the web appendix along with a full description of how all the variables are calculated, descriptive statistics and their data sources.

9 Import Share is a proxy form the elasticity of the supply of exports facing Argentina and therefore the impact that tariffs have on domestic prices. 


\section{Statistical Models}

To evaluate how an industry's characteristics influence its political clout and, therefore, its ability to secure preferential treatment, a series of multi-level logit and multinomial logit models are estimated. The first model only uses subnational political importance (Subnational Production) to measure political clout. In order to compare the influence of political clout measured at the subnational level and at national level, the two "national" level models are estimated which include Production ${ }_{i}$ and Political Concentration ${ }_{i}$ by themselves as well as with their interaction. There is no reason to believe that interested parties cannot pursue parallel lobbying efforts or that some will prefer to flex their political influence only at the subnational or national level. For this reason, two "full" models are estimated that include the subnational and national level measures of political influence. ${ }^{10}$

In order to fully represent the "protection for sale" model, all models include the variables Import Share ${ }_{p^{\prime}}$ IIT $_{i^{\prime}}$ IIT $_{p_{\text {, }}}$ and Import Penetration ${ }_{i}$. The average Wage $_{i}$ paid by an industry is also included in order to take into the potential political clout of labor.

The political influence of an industry is marginally, not absolutely, related to its size. There is no reason to believe that an extra million dollar of production has the same influence on the political clout of a small industry as it does on a large industry. To account for the decreasing marginal benefits of industry size as well as of wages, $\log \left(\right.$ Production $\left._{i}\right)$ and $\log \left(\right.$ Wages $\left._{i}\right)$ are used in the statistical models. Given that the values of Import Penetration include zero, the hyperbolic arcsine is used to take into account the decreasing marginal effects of Import Penetration.

\section{ANALYSIS AND DISCUSSION}

Table 2 reports the results from the logit models of deviations from intraregional free trade. Table 3 reports the results of the multinomial logit model of deviations from Mercosur's CET. The results in both tables fit closely with the expectation that subnational interests influence Argentina's trade policy within Mercosur. 
Table 2. Argentine Deviations from Intra-Regional Free Trade

\begin{tabular}{|c|c|c|c|c|c|}
\hline & \multirow{2}{*}{$\begin{array}{c}\text { Subnational } \\
\text { Model } 1\end{array}$} & \multicolumn{2}{|c|}{ National } & \multicolumn{2}{|c|}{ Full } \\
\hline & & Model 2 & Model 3 & Model 4 & Model 5 \\
\hline \multirow[t]{2}{*}{ Import Share } & -13.56 & -13.65 & -13.77 & -14.21 & -14.25 \\
\hline & $(-0.64)$ & $(-0.64)$ & $(-0.64)$ & $(-0.67)$ & $(-0.67)$ \\
\hline \multirow[t]{2}{*}{ asinh(Import Penetration) } & 0.55 & 0.55 & 0.55 & 0.56 & 0.56 \\
\hline & $(5.25)$ & $(5.20)$ & $(5.16)$ & $(5.27)$ & $(5.25)$ \\
\hline \multirow[t]{2}{*}{$\log$ (Wages) } & -3.59 & -4.13 & -4.55 & -5.89 & -5.99 \\
\hline & $(-1.82)$ & $(-1.83)$ & $(-1.97)$ & $(-2.68)$ & $(-2.72)$ \\
\hline \multirow[t]{2}{*}{$\mathrm{IIT}_{\mathrm{p}}$} & 0.49 & 0.48 & 0.48 & 0.49 & 0.48 \\
\hline & $(2.24)$ & $(2.17)$ & $(2.18)$ & $(2.20)$ & $(2.20)$ \\
\hline \multirow[t]{2}{*}{$\operatorname{IIT}_{\mathrm{i}}$} & -0.24 & -1.07 & -1.03 & -0.72 & -0.70 \\
\hline & $(-0.14)$ & $(-0.60)$ & $(-0.58)$ & $(-0.44)$ & $(-0.43)$ \\
\hline \multirow[t]{2}{*}{ Subnatinal Production } & 22.29 & & & 18.20 & 17.67 \\
\hline & (3.87) & & & (3.33) & $(3.20)$ \\
\hline \multirow[t]{2}{*}{$\log ($ Production $)$} & & 2.09 & -0.45 & 1.24 & 0.23 \\
\hline & & $(2.92)$ & $(-0.19)$ & $(1.89)$ & $(0.11)$ \\
\hline \multirow[t]{2}{*}{ Political Concentration } & & 7.52 & -27.03 & 6.89 & -7.17 \\
\hline & & (1.98) & $(-0.85)$ & (1.99) & $(-0.25)$ \\
\hline $\log (\text { Production })^{*}$ & & & 6.33 & & 2.57 \\
\hline Political Concentration & & & (1.09) & & $(0.50)$ \\
\hline \multirow[t]{2}{*}{ Intercept } & -2.38 & -14.06 & 0.65 & -6.63 & -0.86 \\
\hline & $(-0.65)$ & $(-2.86)$ & $(0.05)$ & $(-1.47)$ & $(-0.07)$ \\
\hline \multirow[t]{2}{*}{$\zeta \varphi$} & 3.38 & 3.59 & 3.54 & 3.16 & 3.15 \\
\hline & $(5.68)$ & $(5.65)$ & $(5.64)$ & $(5.60)$ & $(5.59)$ \\
\hline Log-likelihood & -577.41 & -580.32 & -579.70 & -574.35 & -574.22 \\
\hline AIC & 1170.81 & 1178.63 & 1179.39 & 1168.70 & 1170.44 \\
\hline $\mathrm{BIC}$ & 1227.15 & 1242.00 & 1249.80 & 1239.11 & 1247.90 \\
\hline $\mathrm{N}$ & 8446 & 8446 & 8446 & 8446 & 8446 \\
\hline \multicolumn{6}{|l|}{ Likelihood ratio tests } \\
\hline & 4 vs 1 & 4 vs 2 & 3 vs 2 & & 5 vs 4 \\
\hline$\chi^{2}$ & $\chi_{(2)}^{2}=3.54$ & $\chi_{(1)}^{2}=11.59$ & $\chi_{(1)}^{2}=1.15$ & & $\chi_{(1)}^{2}=0.48$ \\
\hline \multirow[t]{2}{*}{$\mathrm{P}$-value } & 0.17 & 0.00 & 0.22 & & 0.49 \\
\hline & 5 vs 1 & 5 vs 2 & 5 vs 3 & & \\
\hline$\chi^{2}$ & $\chi_{(3)}^{2}=4.02$ & $\chi_{(2)}^{2}=11.49$ & $\chi_{(1)}^{2}=9.49$ & & \\
\hline P-value & 0.25 & 0.00 & 0.00 & & \\
\hline
\end{tabular}

Multilevel logit with random intercepts estimated using gllamm in STAT 12.

Cluster adjusted z-scores in parentheses. Bold entries are significant at the 0.05 level or better. 
Table 3. Argentine Deviations from Mercosur's Common External Tariff

\begin{tabular}{|c|c|c|c|c|c|}
\hline & \multirow{2}{*}{$\begin{array}{c}\text { Subnational } \\
\text { Model } 1\end{array}$} & \multicolumn{2}{|c|}{ National } & \multicolumn{2}{|c|}{ Full } \\
\hline & & Model 2 & Model 3 & Model 4 & Model 5 \\
\hline \multicolumn{6}{|l|}{ Liberalizing Deviations } \\
\hline \multirow[t]{2}{*}{ Import Share } & 63.62 & 62.51 & 62.46 & 61.06 & 61.07 \\
\hline & $(8.40)$ & $(8.27)$ & $(8.27)$ & $(8.11)$ & $(8.10)$ \\
\hline \multirow[t]{2}{*}{ asinh(Import Penetration) } & 0.44 & 0.37 & 0.37 & 0.45 & 0.44 \\
\hline & $(2.84)$ & $(2.28)$ & $(2.29)$ & $(2.80)$ & $(2.74)$ \\
\hline \multirow[t]{2}{*}{$\log$ (Wages) } & -0.34 & 0.09 & -0.05 & -0.54 & -0.60 \\
\hline & $(-0.29)$ & $(0.07)$ & $(-0.04)$ & $(-0.42)$ & $(-0.45)$ \\
\hline \multirow[t]{2}{*}{$\mathrm{IIT}_{\mathrm{p}}$} & 0.30 & 0.34 & 0.33 & 0.30 & 0.30 \\
\hline & $(1.50)$ & $(1.70)$ & $(1.68)$ & (1.48) & $(1.48)$ \\
\hline \multirow[t]{2}{*}{$\mathrm{IIT}_{\mathrm{i}}$} & 1.76 & 1.69 & 1.66 & 1.63 & 1.66 \\
\hline & $(1.78)$ & $(1.69)$ & (1.66) & $(1.66)$ & $(1.69)$ \\
\hline \multirow[t]{2}{*}{ Subnatinal Production } & -7.37 & & & -7.98 & -8.22 \\
\hline & $(-1.80)$ & & & $(-2.02)$ & $(-2.06)$ \\
\hline \multirow[t]{2}{*}{$\log$ (Production) } & & -0.01 & -0.30 & 0.56 & 0.27 \\
\hline & & $(-0.01)$ & $(-0.24)$ & (1.38) & $(0.22)$ \\
\hline \multirow[t]{2}{*}{ Political Concentration } & & -1.19 & -5.56 & -0.47 & -4.40 \\
\hline & & $(-0.58)$ & $(-0.35)$ & $(-0.23)$ & $(-0.28)$ \\
\hline $\log$ (Production) $^{*}$ & & & 0.85 & & 0.75 \\
\hline Political Concentration & & & $(0.29)$ & & $(0.25)$ \\
\hline \multirow[t]{2}{*}{ Intercept } & -3.63 & -4.17 & -2.37 & -5.90 & -4.27 \\
\hline & $(-1.57)$ & $(-1.63)$ & $(-0.34)$ & $(-2.16)$ & $(-0.61)$ \\
\hline \multicolumn{6}{|l|}{ Protectionist Deviations } \\
\hline \multirow[t]{2}{*}{ Import Share } & 4.21 & 10.59 & 10.82 & 9.06 & 9.10 \\
\hline & $(0.31)$ & $(0.81)$ & $(0.83)$ & $(0.67)$ & $(0.67)$ \\
\hline \multirow[t]{2}{*}{ asinh(Import Penetration) } & 0.52 & 0.73 & 0.70 & 0.60 & 0.60 \\
\hline & $(3.07)$ & $(4.17)$ & (3.93) & $(3.40)$ & $(3.41)$ \\
\hline \multirow[t]{2}{*}{$\log$ (Wages) } & -0.70 & -1.91 & -2.07 & -2.36 & -2.35 \\
\hline & $(-0.59)$ & $(-1.45)$ & $(-1.55)$ & $(-1.80)$ & $(-1.77)$ \\
\hline \multirow[t]{2}{*}{$\mathrm{IIT}_{\mathrm{p}}$} & 1.91 & 1.94 & 1.95 & 1.93 & 1.93 \\
\hline & $(10.84)$ & $(10.83)$ & $(10.85)$ & $(10.79)$ & $(10.78)$ \\
\hline \multirow[t]{2}{*}{$\mathrm{IIT}_{\mathrm{i}}$} & 0.87 & 0.83 & 0.92 & 0.79 & 0.77 \\
\hline & $(0.87)$ & $(0.83)$ & $(0.91)$ & $(0.81)$ & $(0.78)$ \\
\hline \multirow[t]{2}{*}{ Subnatinal Production } & 10.72 & & & 7.87 & 7.84 \\
\hline & $(3.00)$ & & & (2.10) & (2.07) \\
\hline \multirow[t]{2}{*}{$\log$ (Production) } & & 1.32 & 0.55 & 0.80 & 0.75 \\
\hline & & $(3.40)$ & $(0.44)$ & (1.75) & $(0.62)$ \\
\hline
\end{tabular}




\begin{tabular}{|c|c|c|c|c|c|}
\hline & \multirow{2}{*}{$\begin{array}{c}\text { Subnational } \\
\text { Model } 1\end{array}$} & \multicolumn{2}{|c|}{ National } & \multicolumn{2}{|c|}{ Full } \\
\hline & & Model 2 & Model 3 & Model 4 & Model 5 \\
\hline \multirow[t]{2}{*}{ Political Concentration } & & 4.91 & -5.00 & 3.84 & 3.07 \\
\hline & & $(2.40)$ & $(-0.31)$ & $(2.01)$ & $(0.20)$ \\
\hline $\log (\text { Production })^{*}$ & & & 1.86 & & 0.16 \\
\hline Political Concentration & & & $(0.62)$ & & $(0.05)$ \\
\hline \multirow[t]{2}{*}{ Intercept } & -3.84 & -10.03 & -5.60 & -6.18 & -5.95 \\
\hline & $(-1.65)$ & $(-3.86)$ & $(-0.78)$ & $(-2.25)$ & $(-0.85)$ \\
\hline \multirow[t]{2}{*}{$\zeta \varphi$} & 2.83 & 2.85 & 2.85 & 2.78 & 2.78 \\
\hline & $(10.47)$ & $(10.46)$ & $(10.44)$ & $(10.43)$ & $(10.41)$ \\
\hline Log-likelihood & -3280.34 & -3366.43 & -3362.56 & -3325.74 & -3283.02 \\
\hline AIC & 6590.68 & 6766.86 & 6763.11 & 6681.48 & 6608.05 \\
\hline $\mathrm{BIC}$ & 6696.31 & 6886.57 & 6896.91 & 6787.11 & 6755.92 \\
\hline $\mathrm{n}$ & 8449 & 8449 & 8449 & 8449 & 8449 \\
\hline \multicolumn{6}{|l|}{ Likelihood ratio tests } \\
\hline & 4 vs 1 & 4 vs 2 & 3 vs 2 & & 5 vs 4 \\
\hline$\chi^{2}$ & $\chi_{(4)}^{2}=-90.85$ & $\chi_{(2)}^{2}=81.32$ & $\chi_{(2)}^{2}=7.75$ & & $\chi_{(2)}^{2}=85.32$ \\
\hline \multirow[t]{2}{*}{ P-value } & 1.00 & 0.00 & 0.02 & & 0.00 \\
\hline & 5 vs 1 & 5 vs 2 & 5 vs 3 & & \\
\hline$\chi^{2}$ & $\chi_{(6)}^{2}=5.42$ & $\chi_{(4)}^{2}=166.82$ & $\chi_{(2)}^{2}=159.07$ & & \\
\hline P-value & 0.49 & 0.00 & 0.00 & & \\
\hline
\end{tabular}

Hypothesis 1 states that industries with greater relative subnational importance are more likely to receive protection and less likely to face greater liberalization. For protectionist deviations from free trade, the estimated coefficients of Subnational Production are positive and statistically significant across all models (see Table 2). In the case of the "subnational model" (Model 1), a difference of one standard deviation of Subnational Production (0.07) is associated with an difference in the odds-ratio of receiving protection of $370 \%$, while an increase of 0.01 in the value of Subnational Production is associated with an increase of $25 \%$ in the odds-ratio of receiving protection.

Exact changes in the likelihood of deviations from free trade are difficult to calculate because of the inherently interactive nature of the non-linear model as well as the multi-level nature of the models. By looking at the predicted probabilities of specific industries we can gauge how the average the likelihood of protection varies across different values of Subnational Production. ${ }^{11}$ For

11 The predicted probability of protection is calculated using the observed values on all the other covariates for a given industry, with its given value of Subnational Production, and the average in taken. 
instance, products associated with the manufacture of starches and starch products (the industry with the value of Subnational Production closest to the mean value of 0.058 ) are, on average, $2.87 \%$ more likely to receive protection that products associated with the manufacture of "other" basic chemical products (Subnational Production $=0.0349$ ). This change may seem small, but given that the base probability of a protectionist deviation from free trade is $5 \%$, the difference represents a substantively large change in the likelihood of protection. The difference in the average observed likelihood of protection faced by producers of bottled fruit juices (Subnational Production $=0.0532$ ) and by producers of carpets and rugs (Subnational Production $=0.007$ ) is $29.9 \%{ }^{12}$

Higher levels of Subnational Production are also associated with a higher likelihood of protectionist deviations from Mercosur's CET. An increase of one standard deviation in Subnational Production is associated with an increase in the odds-ratio of $126 \%$. Producers of starches and starch products (bottled fruit juices) have a $30.5 \%$ (33.3\%) greater likelihood of protectionist deviations than those associated with "other" basic chemical products (carpets and rugs).

Hypothesis 1 also indicates that industries of relative subnational importance should be less likely to face liberal deviations from Mercosur's CET. Overall, there is strong evidence to support this position. The estimated coefficient for Subnational Production across all models has a negative and statistically significant association with liberal deviations. Based on Model 1, the difference in one standard deviation in Subnational Production is associated with a $60 \%$ smaller odds-ratio. This would seem to indicate that subnationally important industries were able to resist efforts to liberalize their products.

The degree to which politicians take into account the aggregate welfare effects of their policies is directly related to the extent to which parochial interests influence policy outcomes. Hypothesis $2 b$ indicates that, if the preference of policymakers depend on the interests of specific geographic constituencies, the terms-of-trade effects of policies (measured by Import Share) should have a non-negative relationship with protection. Across all the models of deviations from free trade, the estimated coefficients of Import Share are negative, but not statistically significant. The estimated relationship between Import Share and protectionist deviations from the CET is also non-negative across all models. These results contradict the idea that national welfare was taken into account when determining which industries received protection (Hypothesis 2a). Rather, it would seem that protections concessions were based on the need to reduce political opposition to the formation of Mercosur and ignored aggregate welfare (Hypothesis 2b).

The results presented in Table 3 indicate that aggregate welfare was taken into consideration when determining liberal deviations from the CET. Across

12 For graphs of predicted probabilities using the average value approach see Graphics 1 and 2 in the web appendix. 
all models, as suggested by Hypothesis 2a, Import Share as a strong positive association with greater trade liberalization. A change in one standard deviation of Import Share (0.005) is associated with an increase in the odds of a liberal deviation of approximately $37 \%$. It would seem that policymakers sought to remove barriers to trade on products where liberalization would have had positive terms-of-trade effects, lowering consumer prices. This coincides with the argument that Argentine authorities wanted to pursue a quick and substantial liberalization of the economy in order to help control inflation (Campbell et al. 1999).

Hypotheses 3 states that products exhibiting a higher level of intra-industrial trade $\left(I I T_{p}\right)$ should be more likely to receive preferential treatment. The degree of $I I T_{p}$ has a clear positive relationship with greater protection. In the case of Model 1, an increase of one standard deviations of $I I T_{p}(0.22)$ is associated with a $52 \%(11 \%)$ increase in the odds-ratio of a product benefiting from a protectionist deviation from the CET (intra-regional free trade). The average observed likelihood of protections deviations from the CET (free trade) increases 5.7\% $(8.3 \%)$ with an increase from the mean value of $I I T_{p}(0.0)$ to the value of the third quartile (0.0189). This suggests that Argentina's political system encourages politicians to cater to specific geographic constituencies and that individual firms within these constituencies were able to successfully lobby for protection. At the same time, the degree of IIT faced by the industry as a whole (IIT $)_{i}$ demonstrates no statistically significant relationship with either protectionist or liberal deviations.

The degree of Import Penetration faced by an industry has a significant and positive relationship with protectionist deviations from free trade as well as with protectionist deviations from the CET. This suggests that producers in decline relative to their international (Mercosur) competitors may have been able to lobby for greater protection. However, the substantive influence of Import Penetration is relatively limited. Moving from the minimum value of Import Penetration to the value of the third quartile is associated with an increase in the relative risk of protectionism from the CET (free trade) of only $12 \%(10 \%)$. It is interesting to note that higher levels of Import Penetration are also associated with liberal deviations from the CET, this may indicate that politicians sought to liberalize products which were already imported in significant quantities in order to satisfy internal demand; however, the substantive effect is also very limited.

Standard statistical models of the endogenous determinants of trade protection tend to use measure of an industry's importance within the national economy and its political concentration as proxies for its political clout. This may make sense when the politics of trade policy is not strongly rooted in the interests of subnational constituents and if protection is "for sale" via political contributions independent of their origin. If we were to ignore the relative subnational importance of industries in Argentina, we might be led to believe that an industry's political clout stems from its role within the national economy and 
its political concentration. For deviations from free trade and for protectionist deviations from the CET, Model 2 coincides with the standard predictions of the trade policy literature. Within this model Production and Political Concentration have a positive and significant association with protection. In the case of Model 3, which incorporates an interaction between Production and Political Concentration, the addition of the interaction effect causes both variables to lose their statistical significance. This is not especially uncommon in logistic regressions, since they are inherently interactive. ${ }^{13}$

When both subnational and national level indicators of political clout are taken into account (Models 4 and 5), it becomes evident that the relative subnational importance of an industry provides an important indicator of whether an industry receives protection. In all of these models, Subnational Production has a statistically and substantively significant positive relationship with protection. Likelihood ratio tests of the "full" models versus the "national" models demonstrate that taking into account Subnational Production better predicts which products and industries received protection. For both deviations from free trade and from the CET, when Subnational Production is taken into account absolute size of an industry (Production) no longer has a significant association with greater protection. These results indicate that the relative subnational importance of an industry plays a fundamental role within the policymaking process. Moreover, when Subnational Production is used to measure political clout, the absolute size of an industry no longer functions as a good proxy for an industry's political clout.

The superiority of Subnational Production as a measure of political clout also emerges when comparing the "subnational" model with the other models. Although the "subnational" and "national" models are not nested, we can use their Bayesian Information Criterion (BIC) and the Akaike Information Criterion (AIC) to assess which models are closer to the "true" model. For both deviations from free trade and from the CET, the lower AICs and BICs of Model 1 provide strong evidence in favor for the simpler subnational model (Raftery 1995). Not only does the use of Subnational Production provide a better fit to the data, it also provides a more direct and intuitive indicator of subnational importance, eliminating the need for a difficult to interpret interaction between Production and Political Concentration.

Comparing the "subnational" and "full" models also provides evidence of the superiority of the subnational models. In both sets of models the likelihood ratio tests indicate that incorporating Production and Political Concentration as well as their interaction provide no additional information (Model 4 vs. Model 1 and Model 5 vs. Model 1). The smaller values of the BICs and AICs of subnational

13 The low values of the t-statistics for the interactions are confirmed using the procedures suggested by Norton, et. al. (2004). 
models also provide evidence that the simpler "subnational" model better reflects the political process behind Argentina's trade policy decisions.

These results should not be taken to indicate that large industries did not receive preferential treatment within Mercosur. Important industries with the national economy are almost always important within at least one subnational jurisdiction. Rather, the evidence presented here indicates that the political clout of Argentine industries stems, in great part, from their relative role within the subnational economies that they inhabit. The importance of industries where voters live and work that plays a critical role in determining their political clout and, therefore, whether they receive preferential treatment.

\section{CONCLUSION}

This article examines the relationship between the economic interests of geographically specific constituents and trade protection. It is hypothesized that, given the political importance of geographically specific constituents within Argentine politics, industries of relative importance within its provinces will be more likely to receive protection. This is because the specific economic interests of constituents influence the preferences of politicians and policymakers. This also means that relatively important industries at the subnational level also have greater influence over their representatives that their size within the national economy would otherwise indicate. Although specific institutional arrangements influence the overall likelihood and level of protectionism, which industries receive protection depends on their relative importance within the jurisdictions that they inhabit.

Failure to take into account the economic interests of electoral jurisdictions can generate a misunderstanding of the interaction between domestic economic interests and political institutions that produces trade policy decisions. We know that party strength, the number of veto-points, and presidentialism influence the susceptibility of policymakers to private interests and generate tendencies towards protectionism or free trade. However, these studies do not give us a clear picture of the demand-side of the determinants of economic policy. Focusing only on the absolute size of an industry and its political, or even, geographic concentration overlooks one of the most important determinates of which industries receive protection - the importance of industries were voters live and work.

In countries, like Argentina, where subnational representatives have significant influence, subnational interests directly shape trade policy. Large and small industries within the national economy sway policy because they are important to subnational economies. The location of production relative to other economic activity at the subnational level determines an industry's ability to obtain trade protection. It is not whether an industry is politically concentrated or not, but where the industry is located relative to other economic activities. Political 
influence stems from an industry's importance to the health of local economies where voters live, work, and vote. Although this insight is widely accepted within the literature on United States trade policy, little work has been done to understand how the economic characteristics of geographic constituencies influence the political clout of industries in the federal systems of Latin America. In the case of Argentina, it seems unlikely that legislators act as "constituent servants" as they do in the United Sates, but rather that the logic of provincial party loyalty generates similar trade policy outcomes and influences the political clout of industries in similar ways.

This article has highlighted the importance taking into account how subnational interests influence trade policy and the need to more accurately measure industries' political clout. Recently, scholars have begun to seriously integrate the influence of political institutions and the political concentration of industries into their research; nonetheless, countries' policies have, more often than not, been seen as an amalgam of national level domestic interests interacting with the political or spatial distribution of each industry's activity independent of the distribution of other industries or economic activities. The political concentration of an industry cannot be taken as a proxy for its relative importance within political jurisdictions. The importance of a highly concentrated industry within a particular jurisdiction depends directly on the location of other economic activities. Focusing only on the political concentration and relative national importance of an industry may seem to explain much of the variation in commercial policy across industries, but doing so misspecifies a principal source of an industry's influence. For this reasons, measures of political clout cannot ignore the overall economic geography of the country and the relationship among different types of economic activity.

Within the study of Latin American federal systems, scholars have tended to focus on political institutions and party structures to explain policy outcomes, ignoring the economic geography of these countries. As a result, the economic interests of geographically specific constituencies have also been ignored, implicitly discounting the economic interests of voters and subnational economic actors. This research suggests that the failure to take into account the economic geography of jurisdictions can cause scholars to overlook an important determinant of the policymaking process and may generate erroneous conclusions about the interests and forces behind politics in the region.

\section{REFERENCES}

Ames, Barry. 1994. “The Reverse Coattail Effect: Local Party Organization in the 1989 Brazilian Presidential Elections". The American Political Science Review 88(1): 95-111.

Arce, Hugh, Robert Koopman, and Marinos Tsigas. 2008. "Using State-level Simulations in a Political Economy Model of US Trade Policy". Public Choice 135(3-4): 91-107.

Baldwin, David and Meredith Crowley. 2001. "Congressional Voting on International Economic Bills in the 1990s". In Trade, Development and Political Economy: Essays in Honour of 
Anne O. Krueger, edited by Deepak Lal and Richard H. Snape. New York: Palgrave, 231-250.

Baldwin, Richard and Frederic Robert-Nicoud. 2007. "Offshoring: General Equilibrium Effects on Wages, Production and Trade". National Bureau of Economic Research Working Paper $\mathrm{N}^{\circ} 12991$.

Baldwin, Robert and Christopher S. Magee. 2000. Congressional Trade Votes: From NAFTA Approval to Fast-Track Defeat. Washington, DC: Institute for International Economics.

Bennedsen, Morten and Sven E. Feldmann. 2002. "Lobbying Legislatures". Journal of Political Economy 110(4): 919-946.

Bombardini, Matilde and Francesco Trebbi. 2012. "Competition and Political Organization: Together or Alone in Lobbying for Trade Policy?" Journal of International Economics 87(1): 18-26.

Calvo, Ernesto and Marcelo Leiras. 2012. "The Nationalization of Legislative Collaboration: Territory, Partisanship, and Policymaking in Argentina". Revista Ibero-Americana de Estudios Legislativos 2(1): 2-19.

Campbell, Jorge, Ricardo Rozemberg and Gustavo Svarzman. 1999. “El Mercosur en los años 90: de la apertura a la globalización". In Mercosur entre la realidad y la utopía, edited by Jorge Campell. Buenos Aires: Grupo Editor Latinoamericano, 123-227.

Carey, John M. 2000. "Parchment, Equilibria, and Institutions". Comparative Political Science 33(6): 735-761.

Cassing, James, Timothy J. McKeown and Jack Ochs. 1986. "The Political Economy of the Tariff Cycle". The American Political Science Review 80(3): 843-62.

Caves, Richard E. 1976. "Economic Models of Policy Choice in Canada's Tariff Structure". Canadian Journal of Economics 9: 279-300.

Cox, Gary and Mathew McCubbins. 2001. “The Institutional Determinants of Economic Policy Outcomes". In Presidents, Parliaments and Policy, edited by Stephen Haggard and Mathew D. McCubbins. New York: Cambridge University Press, 21-63.

Crisp, Brian F., Maria C. Escobar-Lemmon, Bradford S. Jones, Mark Jones, and Michelle M. Taylor-Robinson. 2004. "Vote-Seeking Incentives and Legislative Representation in Six Presidential Democracies". The Journal of Politics 66(3): 823-846.

Chase, Kerry A. 2005. Trading Blocs: States, Firms, and Regions in the World Economy. Ann Arbor: University of Michigan Press.

Drope, Jeffery M. 2006. “Don't Buy from Me Argentina: Politics, Economics, and Trade Liberalization in Argentina, 1992-2001". Studies in Comparative International Development 41(1): 53-75.

Evans, Carolyn L. 2009. “A Protectionist Bais in Majoritarian Politics: An Empirical Investigation". Economics \& Politics 21(2): 278-307.

Finger, J. Michael and Ann Harrison. 1994. "The MFA Paradox: More Protection and More Trade?". National Bureau of Economic Research Working Paper $N^{\circ} 4751$.

Fordham, Benjamin O. and Timothy J. McKeown. 2003. "Selection and Influence: Interest Groups and Congressional Voting on Trade Policy". International Organization 57(3): 519-549.

Gilligan, Michael J. 1997. “Lobbying as a Private Good with Intra-Industry Trade”. International Studies Quarterly 41(3): 455-471.

Goodhart, Lucy. 2015. "Industry-Level Protection". In The Oxford Handbook of The Political Economy of International Trade, edited by Lisa. L. Martin. New York: Oxford Univerity Press, 159-176.

Grossman, Gene M. and Elhanan Helpman. 1994. "Protection for Sale". The American Economic Review 84: 833-850.

Henisz, Witold J. and Edward Mansfield. 2006. "Votes and Vetoes: The Political Determinants of Commercial Openness". International Studies Quarterly 50(1): 189-212.

Jones, Mark P. 2008. "The Recruitment and Selection of Legislative Candidates in Argentina". In Pathways to Power, edited by Peter Siavelis and Scott Morgenstern. Univerity Park: Pennsylvania State University Press, 41-75. 
Jones, Mark P., Sebastian Saiegh, Pablo T. Spiller, and Mariano Tommasi. 2001. "Keeping a Seat in Congress: Provincial Party Bosses and the Survival of Argentine Legislators". Center of Studies for Institutional Development (CEDI), Fundación Gobierno y Sociedad.

Kono, Daniel Yuichi. 2009. "Market Structure, Electoral Institutions, and Trade Policy". International Studies Quarterly 53(4): 885-906.

Lee, Jong-Wha and Phillip Swagel. 1997. “Trade Barriers and Trade Flows across Countries and Industries". Review of Economics and Statistics 79(3): 372-382.

Leiras, Marcelo. 2007. Todos los caballos del rey: La integración de los partidos políticos y el gobierno democrático de la Argentina, 1995-2003. Buenos Aires: Prometeo.

Lodola, German J. 2011. The Politics of Subnational Coalition Building: Gubernatorial Redistributive Strategies in Argentina and Brazil. Doctoral Dissertation, University of Pittsburgh.

Magee, Stephen P., William A. Brock, and Leslie Young. 1989. Black Hole Tariffs and Endogenous Policy Theory: Political Economy in General Equilibrium. New York: Cambridge University Press.

Maggi, Giovanni and Andrés Rodríguez-Clare. 2000. “Import Penetration and the Politics of Trade Protection". Journal of International Economics 51(2): 287-304.

Mainwaring, Scott. 1999. Rethinking Party Systems in the Third Wave of Democratization: The case of Brazil. Stanford: Stanford University Press.

Marvel, Howard P. and Edward John Ray. 1987. "Intraindustry Trade: Sources and Effects on Protection". Journal of Political Economy 95(6): 1278-1291.

McGillivray, Fiona. 2004. Privileging Industry: The Comparative Politics of Trade and Industrial Policy. Princeton: Princeton University Press.

Micozzi, Juan Pablo. 2013. “Does Electoral Accountability Make a Difference? Direct Elections, Career Ambition, and Legislative Performance in the Argentine Senate". The Journal of Politics 75(1): 137-149.

Micozzi, Juan Pablo. 2014. "From House to Home: Strategic Bill Drafting in Multilevel Systems with Non-static Ambition". The Journal of Legislative Studies 20(3): 265-284.

Milner, Helen and Bumba Mukherjee. 2009. "Democracy and the Skill-Bias in Trade Policy in Developing Countries". Available at SSRN 2182080.

Milner, Helen and B. Peter Rosendorff. 1996. "Trade Negotiations, Information and Domestic Politics". Politics and Economics 8(2): 145-189.

Milner, Helen and B. Peter Rosendorff. 1997. "Democratic Politics and International Trade Negotiations". Journal of Conflict Resolution 41(1): 117-146.

Murillo, María Victoria and Pablo Pinto. 2014. "Heeding to the Losers? Legislators' Trade Policy Preferences and Behavior in the Spotlight". Paper prepared for the 1st Annual Meeting of REPAL. Santiago, Chile.

Norton, Edward C., Hua Wang, and Chunrong Ai. 2004. "Computing Interaction Effects and Standard Errors in Logit and Probit Models". Stata Journal 4:154-67.

Olarreaga, Marcelo, Isidro Soloaga, and Alan L. Winter. 1999. "What's behind Mercosur's Common External Tariff?". World Bank Policy Research Working Paper. Washington, DC.

Pezzola, Anthony. 2013. "States in the Customs House: Institutional Reforms and Structural Change in Mexican Trade Policy". International Studies Quarterly 57(2): 341-355.

Pincus, Jonathan J. 1975. "Pressure Groups and the Pattern of Tariffs". Journal of Political Economy 53: 757-778.

Putnam, Robert D. 1988. "Diplomacy and Domestic Politics: The Logic of Two-Level Games". International Organization 42(3): 427-460.

Raftery, Adrian E. 1995. "Bayesian Model Selection in Social Research". Sociological Methodology 25: 111-163.

Rickard, Stephanie J. 2012. “A Non-Tariff Protectionist Bias in Majoritarian Politics: Government Subsidies and Electoral Institutions". International Studies Quarterly 56(4): 777875. 
Rogowski, Ronald. 1987. "Trade and the Variety of Democratic Institutions". International Organization 41(2): 203-223.

Rogowski, Ronald. 2002. "Trade and Representation: How Diminishing Geographic Concentration Augments Protectionist Pressure in the U.S. House of Representatives". In Shaped by War and Trade, edited by Ira Katznelson and Martin Shefter. Princeton: Princeton University Press, 181-210.

Rogowski, Ronald and Mark Andreas Kayser. 2002. "Majoritarian Electoral Systems and Consumer Power: Price-Level Evidence from the OECD Countries". American Journal of Political Science 46(3): 526-39.

Rogowski, Ronald, Mark Andreas Kayser, and Daniel Kotin. 1999. "How Geographic Concentration Affects Industrial Influence: Evidence from U.S. Data." Paper presented at Annual Meeting of the American Political Science Association. Atlanta.

Rohde, David W. 1991. Parties and Leaders in the Post Reform House. Chicago: University of Chicago Press.

Saiegh, Sebastian. 2004. “The 'Sub-national' Connection: Legislative Coalitions, Cross-voting, and Policymaking in Argentina". In The Argentine Crisis at the Turn of the Millennium: Causes, Consequences, and Explanations, edited by Flavia Fiorucci and Marcus Klein. Amsterdam: Aksant Academic Publishers, 83-96.

Salamon, Lester M. and John J. Siegfried. 1977. “Economic Power and Political Influence: The Impact of Industry Structure on Public Policy". The American Political Science Review 71(3): 1026-1043.

Siavelis, Peter and Scott Morgenstern (eds.). 2012. Pathways to Power: Political Recruitment and Candidate Selection in Latin America. University Park: Penn State Press.

Suárez Cao, Julieta. 2011. “¿Federal en teoría pero unitaria en la práctica?: Una discusión sobre el federalismo y la provincialización de la política en Argentina". Revista SAAP 5(2): 305-321.

Weyland, Kurt. 1996. "Risk-taking in Latin American Economic Restructuring". International Studies Quarterly 40(2): 185-207.

Anthony Pezzola, PhD is currently an Assistant Professor in the College of Integrative Sciences and Arts at Arizona State University. E-mail: apezzola@asu.edu. Supplementary tables and replication data are available at http:/ / www.anthonypezzola.com 
- 